\title{
Land as a constraint on food production
}

\section{By J. C. Bowman, Centre for Agricultural Strategy, University of Reading, Reading RG6 $2 A T$}

The purpose of this paper is to consider the extent to which the area and quality of land limit the level of food production in the UK. As the population and its disposable income have increased so has the land area devoted to non-agricultural activities. In addition, the area of tree planting has been enlarged to replace the depleted reserves of forest. Simultaneously a great deal of research, development, investment and hard work have been devoted to increasing the productivity of the smaller land area available for food production. The outcome has been a substantial success. Though land area for food production has decreased by 831000 hectares (or $3.4 \%$ of the total UK area) between 1955 and 1975 , output per unit area has increased by approximately $3 \%$ linear over the same period. Even taking into account the increase in population and the changes in food demands towards commodities which require more land per unit product, the level of selfsufficiency, for all foods, has increased from about $50 \%$ in 1955 to $54 \%$ in 1975 . For foods which can be produced in the UK the figures are $64 \%$ and $68 \%$ respectively. There are many indications that the changes which have taken place in the past 30 years in the balance between land and food production in the UK should not be extrapolated into the next 25 years as an indication of the likely balance at the end of the century.

On the assumption that land area will continue to be essential as a means of converting solar radiation, through photosynthesis, for food production, an attempt has been made to indicate the constraint which land imposes on the ability of the UK to feed its own population.

\section{The present situation}

The area, quality and relative productivity of land in the UK and in Scotland, Northern Ireland and England and Wales are shown in Table $\mathrm{r}$. The essential features of the situation are as follows: (I) a major part of the land in urban use is found in England and Wales; (2) there is proportionately more forestry in Scotland and Northern Ireland than in England and Wales; (3) more than half the land in agriculture is classed as Grades IV and V, which is of low productivity, and a disproportionately large amount of it is in Scotland; (4) the relative productivities of the five land grades are very approximate and somewhat out-of-date. The extent to which new developments in drainage, husbandry and cultivation have changed these relative productivities is not known. However, per unit of input, it is conceivable that the range of values has widened rather than narrowed; $(5)$ the 
Table I. The land area, use, quality and productivity in the UK

\begin{tabular}{|c|c|c|c|c|c|}
\hline & $\begin{array}{l}\text { England } \\
\text { and Wales }\end{array}$ & Scotland & $\begin{array}{l}\text { Northern } \\
\text { Ireland }\end{array}$ & $\begin{array}{l}\text { United } \\
\text { Kingdom }\end{array}$ & $\begin{array}{c}\text { Relative } \\
\text { productivity } \\
\text { of agricultural } \\
\text { land }\end{array}$ \\
\hline \multicolumn{6}{|l|}{ Agricultural land: } \\
\hline $\begin{array}{l}\text { Grade I } \\
\text { Grade II }\end{array}$ & $\begin{array}{r}2 \cdot 3 \\
11 \cdot 8\end{array}$ & $\begin{array}{l}0.3 \\
2 \cdot 1\end{array}$ & $2 \cdot 6$ & $9 \cdot 7$ & $2 \cdot 0$ \\
\hline Grade III & $39 \cdot 6$ & $11 \cdot 4$ & $40 \cdot 0$ & $30 \cdot 6$ & $I \cdot 0$ \\
\hline Grade IV & 16.0 & $8 \cdot 4$ & 24.9 & $14 \cdot 1$ & 0.5 \\
\hline Grade V & $11 \cdot 3$ & $62 \cdot 2$ & 14.9 & 27.8 & 0.1 \\
\hline $\begin{array}{l}\text { Urban land } \\
\text { Other land in non- }\end{array}$ & $10 \cdot 5$ & $3 \cdot 0$ & $3 \cdot 5$ & $7 \cdot 7$ & \\
\hline $\begin{array}{l}\text { agricultural use including } \\
\text { forestry } \\
\text { Land area (hectares } \times 10^{3} \text { ) }\end{array}$ & $\begin{array}{c}8 \cdot 5 \\
15037\end{array}$ & $\begin{array}{l}12 \cdot 6 \\
7715\end{array}$ & $\begin{array}{l}14 \cdot 1 \\
1348\end{array}$ & $\begin{array}{c}10 \cdot 1 \\
24100\end{array}$ & \\
\hline
\end{tabular}

quality of land which has been used for urban development is thought to be similar to the quality of UK land as a whole. However, there is evidence that, in Scotland, in recent years urban development has taken a disproportionate amount of the scarce, good quality land; (6) forestry has been developed largely on land classed as Grades IV and V and about $80 \%$ of the planting has been in Scotland.

\section{The future}

(1) Transfers of land. Land area for food production is diminishing as a result of the needs of housing, offices, factories, roads, forestry, reservoirs, mining and recreation. In the past 10 years the total loss to agriculture has averaged 65000 hectares/year with approximately equal areas going to urban uses and to forestry. Though the local consequences for appearance and environmental quality may be substantial, the area used for mining, reservoirs and recreation has been comparatively small and is expected to remain so.

The area taken for new forestry each year has declined very recently as a result of an adverse fiscal environment for private forestry. However, this is not anticipated to persist and the state sector of forestry may expand. There is considerable concern about the future of world supplies of timber, and in consequence, substantial support for an expansion of forestry. The area potentially suitable for tree planting in the UK has been estimated at nearly 2100000 hectares. It is considered unlikely that all this land will be afforested by the year 2000 but nearly half, or about 875000 hectares, will be.

Most of the new planting will take place on poor quality land avoiding land currently used for arable farming or permanent grassland. Even if it is assumed that food production will decline in proportion to the area and productivity of land afforested, the total consequence is relatively small. However, there is evidence that the effects of afforestation on farming are by no means all detrimental and, in some cases, are beneficial. Thus, there are well-documented examples of estates on which forestry has been added and the agricultural output on the reduced area left for farming has been as great, or greater than, on the estate as a whole in farming. 
It is therefore highly likely that the estimates of the effects of forestry on food production are an over-estimate. It may be possible, by the appropriate integration of the two activities, to expand or nearly double the forestry area without any adverse effect on farm output.

The area taken for urban activities, of which about $40 \%$ is for housing, may represent a more serious threat to the future potential of farm output. In recent years the area taken for these purposes has been of the order of $25000-30000$ hectares/year. In the past it was assumed that the area taken was related to the increase in population and in its affluence. However, in the last 2 years, the population has decreased and its standard of living has also fallen. Surprisingly, there is as yet no indication of a decline in the land taken for urban use. The explanation probably lies in the fact that in a period of financial stringency it is more attractive to build on green field sites than to rehabilitate derelict and waste land within existing urban areas.

The Centre for Agricultural Strategy (CAS) has recently (CAS, 1976) estimated the possible needs for urban land between now and the year 2000. This estimate was made using three population variants $(58,61$ and 64000000$)$ for 2000 , and four levels $(1,2,3$ and $4 \%$ linear) of increase in disposable income per head. For a population of 58000000 and no increase in disposable income CAS found that a transfer of nearly 3000 hectares/year from agriculture should meet urban needs. At the other extreme, a population of 64000000 in 2000 and an increase of $4 \%$ in disposable income would require a transfer of about 60000 hectares/year from agriculture to urban uses. The most likely estimate was of the order of 12000 hectares/year.

It should be noted that the present rate of transfer of land from agriculture to urban use far exceeds the anticipated need at a time of falling population and disposable income. In addition, it has been estimated that up to $80 \%$ of urban land needs in the years to 2000 could be met by using waste and derelict land in urban areas.

Two other aspects of the effect of urban land use on food production are worthy of note. First, the transfer of land to urban use affects food output, not only in terms of the area lost to agriculture, but also in lowering of productivity in the fringe where the two types of use adjoin. There is, as yet, no measure of the effects of trespass, dogs, litter and vandalism on farm output, but such measures are being collected and will, no doubt, emphasize the severity of the problems of farming at the urban fringe. Second, land used for housing is not a total loss to food production for the activities of keen amateur gardeners can lead to significant output. It is unfortunate that there are no recent measures of the productivity of gardens and allotments as a contribution to food supplies.

The upper and lower limits of new afforestation and new urbanization to 2000 can be converted to values which represent the effect, on farming's productive capacity, of transferring land from agriculture. To quote from the CAS report on Land for Agriculture: 'Projected land requirements for forestry and urban uses to the year 2000 total 9 to $21 \%$ of the crop and permanent grass area or 6 to $14 \%$ of 
the total agriculture area. To assess the impact on agricultural production of land transfer on this scale, it is necessary to convert rough grazing and potential forest land into standardised land equivalents. Assuming that such land is only a quarter to a third as productive as average lowland land, the overall demand for additional forest and urban land is equivalent to 5 to $10 \%$ loss in agricultural production in the absence of technical change'.

(2) Changes in productivity per unit area of land. Until about 1970 the increase in productivity per unit area of land was about $3 \%$ linear per year. Some analyses (Blaxter, 1976; CAS, 1976; S. Wragg, unpublished) have indicated that the rate of increase may be slowing down and for one crop at least, namely sugar beet, may be negative. These analyses have been criticized for several reasons. In particular the conclusions are dependent on the specific years both at the start and end of a series included in the analysis. For reasons of drought, 1975 and 1976 are said to be climatically very atypical years and it is also argued that recently the financial environment has not been conducive to increasing productivity. In spite of these criticisms it would be most unwise to extrapolate a linear rate of $3 \%$ increase in productivity per unit area to the end of the century. Even the $2.5 \%$ (equivalent to $3.1 \%$ linear) projected in the Government White Paper, 'Food from our own Resources' seems optimistic. On the evidence available a rate of 1 to $2 \%$ over the next 25 years would be more appropriate. This is on the assumption that no single substantial change, such as an increase in photosynthetic efficiency, results from a major research finding.

\section{The balance between land lost from agriculture and increased productivity}

Some assessment can be made of the effect on food self-sufficiency of land being transferred from agriculture for forestry and urban use and the counter-balance of increasing agricultural productivity on the remaining area. The balance can be considered in the form of a simple model as shown in Fig. I. Land transfers from

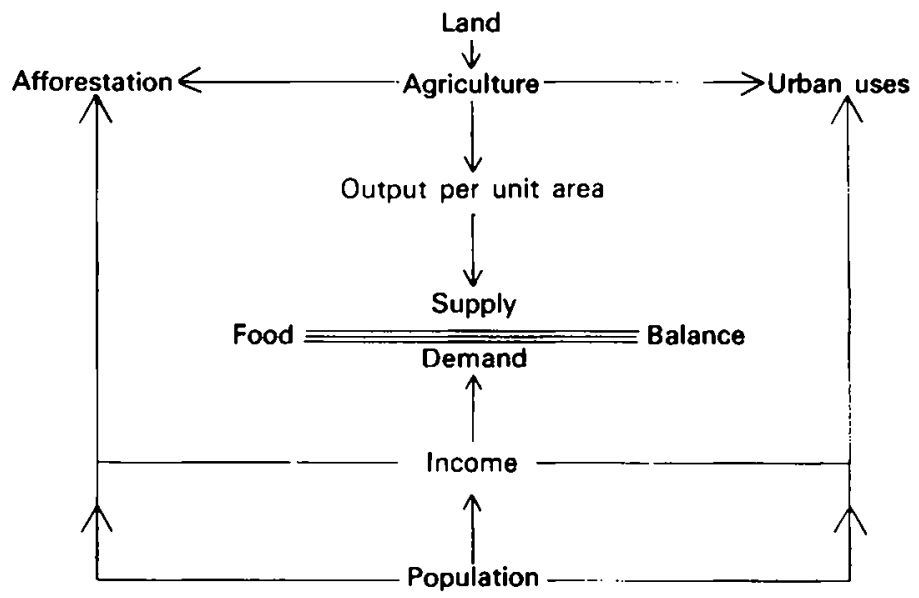

Fig. I. Factors included in determining the effect of land on the balance of the demand for food and the supply of food in the UK. 
agriculture to urban use are considered to depend on population and disposable income change. Land transfers to forestry are highly dependent on the financial environment as affected by government policy. The output of the land left in agriculture will increase at a rate dependent on technology development, financial incentive, climate and not least farmer ability. These factors determine the total supply of food produced in the UK.

The demand for food will depend on population and disposable income and on food preferences. In making the calculations which follow it has been assumed that food preferences will not change. However, it is realized that changes in food preferences and, simultaneously, in the structure of the agricultural industry could lead to very different values for self-sufficiency.

Table 2 shows the balance between the demand for and supply of foods, which can be produced in the UK, which can be achieved under different circumstances of population, income, land loss and growth in output per unit area per year likely to exist in 2000 . It can be seen that for the values of these factors considered the most pessimistic prospect is that it should be just possible to maintain the present level of self-sufficiency of temperate foodstuffs. The most critical factor in the balance is undoubtedly the growth rate in output per unit area. In the past 2 years, in the UK, the output per unit area has fallen. An increase on average of at least I. $5 \%$ year in this factor is essential if the present level of food self-sufficiency is to be maintained.

Table 2. The balance between demand and supply of agricultural output in the year 2000 when non-agricultural demands for land have been met. The degree $\%$ of self-sufficiency in temperate foods that can be attained.

Projected population $\left(\times 10^{6}\right)$

Growth rate in output/unit area per year (\%)

Growth rate in real disposable income per head (\%)

Growth rate in real disposable income per head $(\%)$

\begin{tabular}{|c|c|c|c|c|c|}
\hline \multicolumn{2}{|c|}{$5^{8}$} & \multicolumn{2}{|c|}{ 6I } & \multicolumn{2}{|c|}{64} \\
\hline $1 \cdot 5$ & $3 \cdot 0$ & $1 \cdot 5$ & $3 \cdot 0$ & $1 \cdot 5$ & $3 \cdot 0$ \\
\hline \multicolumn{6}{|c|}{ Land loss equivalent to $5 \%$} \\
\hline $\begin{array}{l}86 \\
80\end{array}$ & $\begin{array}{l}109 \\
102\end{array}$ & $\begin{array}{l}82 \\
76\end{array}$ & $\begin{array}{c}104 \\
96\end{array}$ & $\begin{array}{l}78 \\
72\end{array}$ & $\begin{array}{l}99 \\
92\end{array}$ \\
\hline \multicolumn{6}{|c|}{ Land loss equivalent to $10 \%$} \\
\hline $\begin{array}{l}82 \\
76\end{array}$ & $\begin{array}{r}103 \\
97\end{array}$ & $\begin{array}{l}7^{8} \\
72\end{array}$ & $\begin{array}{l}98 \\
91\end{array}$ & $\begin{array}{l}74 \\
68\end{array}$ & $\begin{array}{l}94 \\
88\end{array}$ \\
\hline
\end{tabular}

Source: Table 9.6 in Land for Agriculture CAS (1976).

\section{REFERENCES}

Blaxter, K. L. (1976). Anim. Prod. 23, 267.

Centre for Agricultural Strategy (1976). Land for Agriculture. Reading: CAS I, Univ. of Reading. 